\title{
Undermining the Refugee Convention: Germany's Civil War Clause and Temporary Asylum
}

\author{
Albrecht Schnabel
}

Ethnic conflicts such as the one raging within and between the republics of the former Yugoslavia are producing alarming numbers of refugees and displaced peoples. Countries which are in close geographic proximity to these conflicts have been literally bombarded with asylum requests from victims of the ethnic wars in the former Yugoslavia. More than 400,000 refugees from the former Yugoslavia came to Germany in 1992 and 1993 alone (Bulletin 1993, 740; Bundesminister des Innern 1994, 4; and Kohl 1993,6). Western Europeans fear that many more refugees will be forced to escape civil conflicts which may break out or intensify in various places across Eastern and Central Europe, and the region of the former Soviet Union. In this light, Germany's new asylum law could be considered an exclusionary defense mechanism applied by a country which, due to its geographic proximity to many refugee producing regions, and its attractiveness as one of the wealthiest countries in Europe, has seen an explosion of asylum applications since the iron curtain was lifted, and ethnic conflict began spreading.

In many aspects Germany's newly revised asylum law represents a major regression from its liberal predecessor. According to the new version of the Asylverfahrensgesetz, stipulations which automatically reject refugee claims from individuals who had come from a "safe country" (Art. 29a), who have insufficient proof for individual political persecution (Art. 25, 30), or who had crossed into Germany coming through a "safe third country" (Art. 26a), make it much more difficult

\footnotetext{
Albrecht Schnabel is a PhD candidate at the Department of Political Studies, Queen's University, Ontario.
}

for potential refugees to claim asylum in Germany (Bundesgesetzblatt 1993a, 1362-83). At the same time, Article 32a of the Ausländergesetz, a new provision regarding the acceptance of refugees from civil wars, was introduced in order to accommodate the increasing number of civil war victims with temporary refuge in Germany (Bundesgesetzblatt 1993b, 1070). However, this new law can be interpreted as a major setback for ethnic refugees. The new law is promoted by the German government as a revolutionary instrument for granting refuge to groups of refugees which do not fit Germany's characteristics of traditional " political refugees," but who are nevertheless in need of assistance (Bundesministerium des Innern 1993). However, according to paragraphs 1 to 3 of Article 32a, these 'quasi-refugees' are granted temporary protection only until the conflict in their homeland has ended, and only if they reject the option of applying for asylum (Bundesgesetzblatt 1993b, 1070). One can thus argue, that this new stipulation is not directed at the inclusion of new groups of refugees, but the effective exclusion of an increasing number of asylum-seekers which, more than most other refugee claimants, match the typical portfolio of a Convention Refugee. Moreover, many victims of ethnic domestic conflict are not persecuted for their political convictions, but solely on the ground of their ethnic and racial affiliation. Even a change of the political landscape often will not resolve the problems of discrimination, oppression and persecution of ethnic minorities, and these 'quasi-refugees' will be subjected to much of the same persecution they originally had fled from.

This new approach at granting temporary refugee status, a vital part of Germany's new asylum policy, poten- tially excludes the largest proportions of Germany's asylum applicants from the opportunity to be granted permanent refugee status. It constitutes a particularly serious shift in policy as it challenges the Geneva Refugee Convention and as it promotes new and increasingly restrictive standards for industrialized nations in dealing with rising numbers of refugees from ethnic civil conflicts. Few groups of migrants fit the definition of a 'Convention Refugee' better than victims of ethnic wars. The evolving practice of categorizing these refugees as 'civil war refugees' is an attempt at wilfully depriving this group which Hannah Arendt described as the 'modern refugees' (Höfling 1993, 38) of the opportunity to apply for asylum in order to evade threats to their livelihood which are not simply limited to the duration of military conflict. Such action totally underestimates the dynamics of ethnic conflicts, wars that do not simply come to an end with the cessation of military activities.

During the Third Reich, members of the German Jewish Community were denied refugee status in many countries because they had not yet been physically persecuted by German authorities. Once the genocide of German Jews by the hands of Nazi authorities had begun, however, it was often too late for an escape. Many Jews who could have been rescued, became victims of systematic ethnic persecution, a low-level conflict which never developed into open civil war. Jews were not persecuted because of their political beliefs, but because of their religious and ethnic origin. Much like the victims of many of today's civil conflicts, they, too, were 'modern refugees,' in contrast to the much more narrow classical definition offered by the 1951 Geneva Refugee Convention and the 1967 Protocol. What, then, could be 
better proof for the potentially explosive nature of ethnic persecution and oppression in post-War rump Yugoslavia or Bosnia than the ethnic genocide currently being committed against members of various ethnic groups? Who could have justifiably sent back Jewish refugees to Germany after it would have won the war and the Nazi regime would still have been in power?

Granting victims of ethnic conflict anything short of full-fledged refugee status, is undermining the basis of the Geneva Refugee Convention. The Convention was created to protect the innocent. One could even argue that ethnic refugees are in a weaker position than classical political refugees: after all, political refugees are persecuted partly because of their own doing, as they choose to practice their human right to political freedom and freely chose their political orientation, while ethnically persecuted people have no choice in choosing their identity. They are the most vulnerable group of refugees, and they deserve the highest degree of compassion. Ethnic persecution cannot be degraded to the status of involuntary victims of war.' To do so renders current standards of human rights and refugee conventions useless if not hypocritical in nature.

If the German approach to civil war refugees passes the international community's judgement without fundamental criticism, then the road is paved for a more broader application of this new approach. Refugee status will be robbed of its permanency, and the asylum-seeker's hope to have found a safe haven will turn into an illusion. Once formal fighting has stopped, these people will be asked to return 'home' to ethnic oppression and persecution. The challenge for other nations to follow Germany's example is great, as such an approach will prob. ably deter many potential refugees from seeking asylum in the first place; and as it will give refugee receiving nations more control over the number of permanently residing refugees, while maintaining the appearance of providing safe havens for those who flee persecution and death.

This new German policy has to come under close scrutiny. Needless to say, many countries will hope for a quiet acceptance of this new approach, as it can then be applied by them as well. As many refugee receiving countries are reinterpreting their asylum policies in ways that favour more sophisticated ways at refining exclusive measures over the inclusive nature of the meaning and purpose of refugee law, this approach only manifests the prospects for a 'fortress Germany,' a 'fortress Europe,' or a 'fortress First World.' If receiving societies are not any more able to offer asylum to anyone who deserves it, proactive measures directed at root-causes for forced migration have to be pursued if justice is to be done according to the principles established by international norms of human rights and refugee protection (United Nations 1988, Article 14).

\section{References}

Bulletin. 1993. "Asylbewerberzahlen in August 1993." No.70, September 7.

Bundesgesetzblatt. 1993a. "Neufassung des Asylverfahrensgesetzes." Z 5702 A, no.41, August 5.

Bundesgesetzblatt. 1993b. "Gesetz zur Änderung asylverfahrens-, ausländerund staatsangehörigkeitsrechtlicher Vorschriften." Z 5702 A, no.33, Juli 1.

Bundesministerium des Innern (Federal Ministry of the Interior). 1994. "Asylbewerberzahlen für den Monat Dezember 1993 und für das Jahr 1993." Das Bundesministerium des Innern teilt mit, January 5.

_. 1993. Das Neue Asylrecht. Bonn: Osang Verlag.

Bettina, Höfling. 1993. "Überlegungen zu aktuellen Fluchtbewegungen und deren Beurteilung." Politische Studien 44, no. 330, July/August.

Helmut, Kohl. 1993. "Policy Statement on the Current State of German-Turkish Relations; Combating Violence and Extremism; and Measures to Improve the Integration of Foreigners in Germany." Statement and Speeches 16, no.9, June 16.

United Nations. 1988. 1948 Universal Declaration of Human Rights. New York: United Nations Department of Public Information. 口

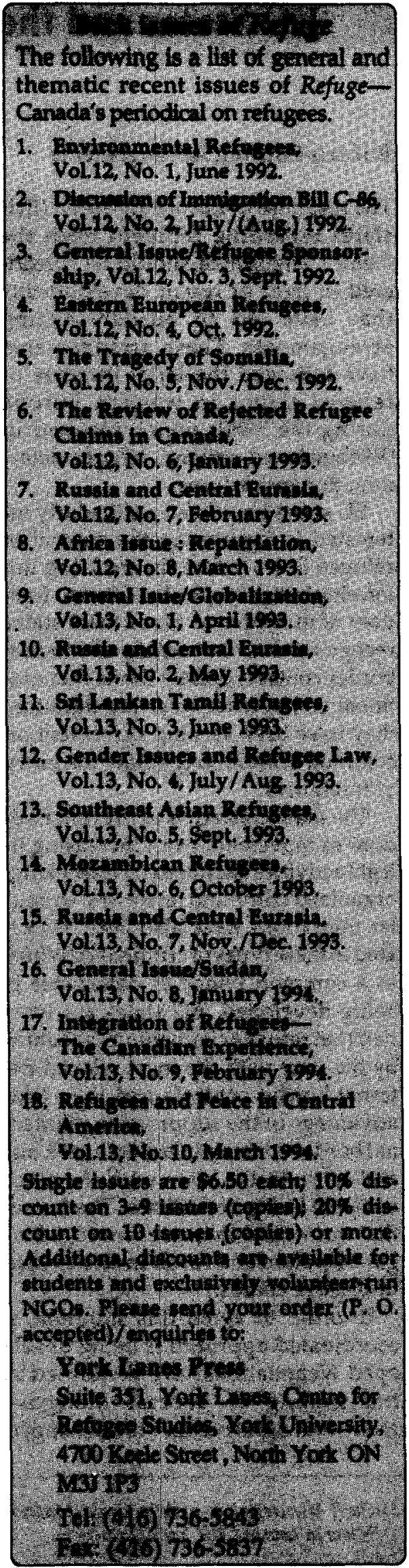

